\title{
Maturation Time and Daily Grain Yield of Sorghum in the Tropics ${ }^{1,2}$
}

\author{
H. M. Pava, A. Sotomayor-Rios, and D. E. Weibel ${ }^{3}$
}

\begin{abstract}
Differences in maturation time and daily grain yield were sought among cultivars and hybrids of sorghum (Sorghum bicolor (L.) Moench) grown in the tropics. Seven lines were used as males in crosses with three cytoplasmicgenetic male-sterile lines to produce 21 hybrids. Formation of the black layer (BL) was used as criterion for physiologic maturity. The male-parental lines and their hybrids were evaluated for grain yield/day from planting to midbloom (GYMB), from planting to BL formation (GYBL), and from midbloom (MB) to BL. formation (GYMB-BL), and for total grain yield at BL formation (GY).

When results for the hybrids of each female line were averaged over the seven male-parental lines, hybrids of the female 'Redlan' were first to reach MB and BL. formation, and they produced the largest GYMB and GYBL. When results for the hybrids of each male-parental line were averaged over the three female lines, hybrids of the males 6,9 , and 10 were among the first to reach $\mathrm{MB}$ and $\mathrm{BL}$ formation, and were highest in GYMB, GYBL, GYMB-BL, and GY. For individual hybrids, differences in both maturation time and GY contributed to differences in daily grain yield, but the greater influence appeared to be that of GY. However, in five of the seven sets of hybrids having a given male parent (e.g., A4, B4, and C4), the hybrid (with Redlan in each case) that was first to reach MB produced a GYMB equal to or higher than those of the hybrids that were slower to reach MB. Also in four of the seven sets of hybrids, the hybrid (with Redlan in three cases) that was first to reach BL formation had a GYBL higher than those of the later maturing hybrids. When the male-parental lines were selfed, lines 6,9 , and 10 produced the highest GY, GYMB, GYBL, and GYMB-BL. These lines were among the five earliest. In the tropics high yield/day and rapid maturation rate may be very desirable characteristics, and the current research identified hybrids with these characteristics. Redlan seems promising as a female parent for such desirable hybrids. Males 6, 9, and 10 seem promising as parent for GY, but they have some undesirable agronomic or quality characteristics.
\end{abstract}

\section{INTRODUCTION}

The longer the growth and developmental period for a particular crop of sorghum (Sorghum bicolor (L.) Moench) in a favorable environment, usually the more dry matter it will produce. However, yield/day may be higher for plants with shorter growth periods than for plants with longer growth periods. In tropical areas where the environment does not limit crop production and where good cultivating and management practices are used, three or more harvests are possible each year. Thus, under these conditions the goal is to obtain the greatest possible yield/year.

' Manuscript submitted to Editorial Board April 6, 1978.

2 Journal Article 3349 of the Agri. Exp. Stn., Okla. State Univ., Stillwater, Oklahoma.

${ }^{3}$ Graduate Student, Department of Agronomy, Oklahoma State University, Stillwater, Okla.; Plant Geneticist, SEA, USDA, Mayagüez Institute of Tropical Agriculture, Mayagüez, Puerto Rico; and Professor, Department of Agronomy, Oklahoma State University, Stillwater, Okla. 
Variety evaluation and selection to determine yield/day (from planting to maturity), yield/crop, and number of crops/year become essential.

The formation of the black layer (BL) in the hilum area of the caryopsis has been used recently for evaluation of physiologic maturity in corn (Zea mays L.) (1, 2, 5) and sorghum. Studying sorghum, Quinby (6) found. that although the hilar layer darkened from day to day, the time at which translocation into the endosperm ceased could not be determined from the color of the BL. The use of BL formation as an indicator of physiologic maturity of grain sorghum was studied by Eastin et al. (3). They found that BL formation at the point of kernel attachment coincided closely with the cessation of translocation of $\mathrm{C}^{14}$ into the kernel. They concluded that BL formation indicated physiologic maturity or maximum accumulation of dry matter.

Kumar (4) used BL formation to determine the date of maximum accumulation of dry matter in grain sorghum. He found that the daily rate of dry matter accumulation in hybrids under nonirrigated conditions increased from early to medium to late maturity groups for all periods studied: planting to midbloom (MB), planting to $\mathrm{BL}$ formation, and $\mathrm{MB}$ to BL formation. Under irrigated conditions the daily dry matter accumulation also increased from early to medium to late maturity groups for the period from planting to $\mathrm{MB}$. However, the daily accumulation was similar for all maturity groups for the period from planting to $\mathrm{BL}$ and decreased from early to medium to late maturity groups for the period $\mathrm{MB}$ to $\mathrm{BL}$.

The BL formation allows precise determination of the length of time from planting and from anthesis to physiologic maturity. Thus it allows calculation of grain production (daily dry matter accumulation) for the periods from planting to $\mathrm{MB}$, planting to $\mathrm{BL}$ formation, and $\mathrm{MB}$ to $\mathrm{BL}$. In this study BL formation was used as an aid in the search for differences in daily yield of grain among sorghum hybrids grown in the tropics.

\section{MATERIALS AND METHODS}

Seven grain sorghum lines (table 1) were selected from the Sorghum Conversion Program (9) and crossed with three cytoplasmic-genetic malesterile female lines-'Combine Kafir-60', 'Martin', and 'Redlan'-to produce $21 \mathrm{~F}_{1}$ hybrids. The male-parental lines were designated 4 through 10 and the female lines as $\mathrm{A}, \mathrm{B}$, and $\mathrm{C}$ (table 1); the hybrids were designed as A4, B4, C4, A5, etc., through $\mathrm{C} 10$. The grain yield and agronomic characteristics of the seven male-parental lines were evaluated by Sotomayor-Ríos and Miller (7).

The male-parental lines and their hybrids were grown at the Isabela Experiment Farm of the Mayagüez Institute of Tropical Agriculture 
TABLE 1.-Sorghum lines used to produce hybrids for grain-yield study at Isabela, P. R.

\begin{tabular}{|c|c|c|}
\hline $\begin{array}{c}\text { Line } \\
\text { number } \\
\text { or } \\
\text { letter }\end{array}$ & Description & Origin \\
\hline \multicolumn{3}{|c|}{ Male lines } \\
\hline 4 & IS 12526C (BTx406 × PI147837) (SC0006) & Ethiopia \\
\hline 5 & IS 12666, TAM2566 (SC0175-9) (BTx3105 × PI276842) & Ethiopia \\
\hline 6 & IS $12666(\mathrm{BT} \times 3105 \times$ IS 12666) (SC0175-14E) & Ethiopia \\
\hline 7 & (IS $2930 \times$ IS3922), sel 74CS & Texas \\
\hline 8 & (SC0599-9-3) (BTx406 × Rio) & Missisippi \\
\hline 9 & IS 12666 sel $(\mathrm{BT} \times 3105 \times$ PI276842) & Ethiopia \\
\hline \multicolumn{3}{|c|}{ Female lines ${ }^{\prime}$} \\
\hline A & Combine Kafir-60 & Texas \\
\hline $\mathrm{B}$ & Martin & Texas \\
\hline $\mathrm{C}$ & Redlan & Oklahoma \\
\hline
\end{tabular}

' Cytoplasmic-genetic male sterile.

(MITA), SEA, USDA from October 1975 to January 1976. The farm is located about $128 \mathrm{~m}$ above sea level. Temperatures range from 18 to $31^{\circ}$ C. The soil is a Coto clay (an Oxisol), a Tropeptic Haplorthox, clayey, kaolinitic, isohyperthermic, with a $\mathrm{pH}$ of about 5.5. Before planting, a complete fertilizer (15-5-10) was applied at $560 \mathrm{~kg} / \mathrm{ha}$. A supplemental irrigation of about $2.5 \mathrm{~cm}$ of water was applied when the majority of the grain was in the milk stage.

The experimental design was complete blocks with six replications. Each experimental unit consisted of two rows $6 \mathrm{~m}$ long and $101 \mathrm{~cm}$ apart. An area of $3 \mathrm{~m}^{2}$ from each row of each unit was harvested 7 to 10 days after reaching the black layer stage for the determination of grain yield.

The following data were collected: 1) number of days from planting to $\mathrm{MB}$; 2) number of days from planting to BL formation; 3) number of days from $\mathrm{MB}$ to $\mathrm{BL}$ formation; 4) total grain yield (at $14 \%$ moisture) at $\mathrm{BL}$ formation; 5) grain yield/day from planting to MB (GYMB), calculated as total grain yield at $\mathrm{BL}$ formation divided by number of days to $\mathrm{MB} ; 6$ ) grain yield/day from planting to BL formation (GYBL), calculated analogously; and 7) grain yield/day from MB to BL formation (GYMB-BL), calculated analogously.

We analyzed the data from the hybrids, using randomized split plots with the male-parental lines as main plots and the hybrids as subplots. The data from the seven male-parental lines selfed were analyzed separately. We compared means, using Duncan's multiple-range test (8).

\section{RESULTS AND DISCUSSION}

\section{EFFECTS OF FEMALE PARENTS}

The average maturation time and grain yield for the hybrids of each female-parental line are presented in table 2. Hybrids differed signifi- 
cantly in number of days from planting to $\mathrm{MB}$ according to their femaleparental lines. The time and planting to $\mathrm{BL}$ formation also differed significantly between hybrids of the female lines $\mathrm{A}$ and $\mathrm{B}, \mathrm{A}$ and $\mathrm{C}$, and $\mathrm{B}$ and $\mathrm{C}$. Hybrids of line $\mathrm{A}$ were the slowest to reach $\mathrm{MB}$ and to form BL. Time from MB to BL differed significantly between hybrids of lines $\mathrm{A}$ and $\mathrm{B}$ and between hybrids of lines $\mathrm{B}$ and $\mathrm{C}$.

The GYMB was significantly higher for hybrids of line $\mathrm{C}$ than for those of lines A and B, but the GYMB's for hybrids of lines A and B were not significantly different. Similarly, the GYBL was significantly higher for the line $\mathrm{C}$ hybrids than for line A hybrids; however, GYBL did not differ significantly either between line $\mathrm{C}$ and line $\mathrm{B}$ or between line $\mathrm{A}$ and line B hybrids. Neither GYMB-BL nor GY differed significantly according to female-parental line among the hybrids.

TABLE 2.- The average effects of three female sorghum lines on maturation time and grain yield of their hybrids (Puerto Rico, 1976)'

\begin{tabular}{|c|c|c|c|c|c|c|c|}
\hline \multirow{3}{*}{ Female } & \multicolumn{3}{|c|}{ Maturation time (days) } & \multicolumn{3}{|c|}{ Grain yield/day $(\mathrm{kg} / \mathrm{ha})^{3}$} & \multirow{3}{*}{$\begin{array}{l}\text { Total } \\
\text { grain } \\
\text { yield }\end{array}$} \\
\hline & \multicolumn{2}{|c|}{ from planting to } & \multirow{2}{*}{$\frac{\text { from }}{\mathrm{MB} \text { to } \mathrm{BL}}$} & \multicolumn{2}{|c|}{ from planting to } & \multirow{2}{*}{$\frac{\text { from }}{\mathrm{MB} \text { to } \mathrm{BL}}$} & \\
\hline & $\mathrm{MB}^{2}$ & $\mathrm{BL}^{2}$ & & MB & $\mathrm{BL}$ & & \\
\hline & & & & & & & $K g / h a$ \\
\hline A & $61.0 \mathrm{a}^{4}$ & $98.7 \mathrm{a}$ & $37.7 \mathrm{a}$ & $53.7 \mathrm{~b}$ & $33.1 \mathrm{~b}$ & $86.5 \mathrm{a}$ & 3264 a \\
\hline $\mathrm{B}$ & $59.2 \mathrm{~b}$ & $95.5 \mathrm{~b}$ & $36.3 \mathrm{~b}$ & $55.0 \mathrm{~b}$ & $34.1 \mathrm{ab}$ & $90.0 \mathrm{a}$ & $3252 \mathrm{a}$ \\
\hline $\mathrm{C}$ & $57.2 \mathrm{c}$ & $94.9 \mathrm{c}$ & $37.7 \mathrm{a}$ & $59.0 \mathrm{a}$ & $35.4 \mathrm{a}$ & $88.9 \mathrm{a}$ & $3356 \mathrm{a}$ \\
\hline Mean & 59.1 & 96.4 & 37.3 & 55.9 & 34.2 & 88.5 & 3291 \\
\hline
\end{tabular}

'Data are averages for all seven crosses made with each female line (female $\times$ male parental lines 4 through 10).

${ }^{2} \mathrm{MB}=$ midbloom, $\mathrm{BL}=$ formation of black layer.

${ }^{3}$ Yield/day averaged over hybrids and replications.

${ }^{4}$ Means followed by the same letter are not significantly different.

Hybrids of female-parental line $\mathrm{C}$ (Redlan) required the fewest days to reach $\mathrm{MB}$ and $\mathrm{BL}$ formation, yet had the highest GYMB and GYBL.

\section{EFFECTS OF MALE PARENTS}

The average number of days to mature and grain yields for the hybrids of each male-parental line are shown in table 3 . Hybrids of line 5 were the slowest to reach $\mathrm{MB}$ : hybrids of line 4 were the slowest to form $\mathrm{BL}$; and hybrids of line 8 were the latest to progress from MB to BL formation. Time to MB was significantly longer for line 5 hybrids than for those of lines 6,8 , and 10 . The time to $\mathrm{BL}$ formation was significantly earlier for hybrids of line 6 than for hybrids of all other male lines. Differences in time to BL formation among the other hybrids according to their maleparental lines were nonsignificant. Time from MB to BL was shortest for hybrids of male lines 5 and 6 and differed significantly from the time required by hybrids of line 8 . 
Hybrids of male lines, 6, 8, 9, and 10 were highest in GYMB, and they were the first to reach MB. Hybrids of lines 4 and 7 were significantly lower than the other lines in GYMB, and they were among the last to reach $\mathrm{MB}$. Hybrids of lines 6, 9, and 10 were highest in GYBL, and they were not significantly different from each other. Hybrids of lines 4 and 7 were significantly lower than the other lines in GYBL. Hybrids of lines 6, 9, and 10 had the highest GYMB-BL. As with GYMB and GYBL, hybrids of lines 4 and 7 had the lowest GYMB-BL. Line 6 hybrids required the fewest days to $\mathrm{MB}$, to $\mathrm{BL}$ formation, and to progress from $\mathrm{MB}$ to $\mathrm{BL}$ formation, yet they had the next-to-highest GYMB, GYBL, and GYMBBL.

In GY, hybrids of the seven male lines ranged from 2091 to $4194 \mathrm{~kg} / \mathrm{ha}$. Hybrids of lines 4 and 7 were significantly lower than hybrids of the other

TABLE 3.- The average effects of seven sorghum lines used as male parents on maturation time and grain yield of their hybrids (Puerto Rico, 1976) ${ }^{1}$

\begin{tabular}{|c|c|c|c|c|c|c|c|}
\hline \multirow{3}{*}{ Male } & \multicolumn{3}{|c|}{ Maturation time (days) } & \multicolumn{3}{|c|}{ Grain yield/day $(\mathrm{kg} / \mathrm{ha})^{3}$} & \multirow{3}{*}{$\begin{array}{l}\text { Total } \\
\text { grain } \\
\text { yield }\end{array}$} \\
\hline & \multicolumn{2}{|c|}{ from planting to } & \multirow{2}{*}{$\frac{\text { from }}{\mathrm{MB} \text { to } \mathrm{BL}}$} & \multicolumn{2}{|c|}{ from planting to } & \multirow{2}{*}{$\frac{\text { from }}{\mathrm{MB} \text { to } \mathrm{BL}}$} & \\
\hline & $\mathrm{MB}^{2}$ & $\mathrm{BL}^{2}$ & & MB & BL & & \\
\hline & & & & & & & $K g / h \alpha$ \\
\hline 4 & $60.1 \mathrm{ab}^{4}$ & $97.3 \mathrm{a}$ & $37.2 \mathrm{ab}$ & $40.5 \mathrm{~d}$ & $24.9 \mathrm{~d}$ & $65.0 \mathrm{c}$ & $2424 \mathrm{c}$ \\
\hline 5 & $60.3 \mathrm{a}$ & $96.4 \mathrm{a}$ & $36.2 \mathrm{~b}$ & $54.7 \mathrm{c}$ & $34.1 \mathrm{c}$ & $91.1 \mathrm{~b}$ & $3281 \mathrm{~b}$ \\
\hline 6 & $58.3 \mathrm{c}$ & $94.4 \mathrm{~b}$ & $36.1 \mathrm{~b}$ & $66.0 \mathrm{ab}$ & $40.6 \mathrm{ab}$ & $105.9 \mathrm{ab}$ & $3824 \mathrm{ab}$ \\
\hline 7 & $59.5 \mathrm{abc}$ & $97.1 \mathrm{a}$ & $37.8 \mathrm{ab}$ & $35.3 \mathrm{~d}$ & $21.5 \mathrm{~d}$ & $55.3 \mathrm{c}$ & $2091 \mathrm{c}$ \\
\hline 8 & $58.6 \mathrm{bc}$ & $96.8 \mathrm{a}$ & $38.2 \mathrm{a}$ & $60.2 \mathrm{bc}$ & $36.4 \mathrm{bc}$ & $92.4 \mathrm{~b}$ & 3522 b \\
\hline 9 & $59.2 \mathrm{abc}$ & $96.7 \mathrm{a}$ & $37.5 \mathrm{ab}$ & $71.0 \mathrm{a}$ & $43.4 \mathrm{a}$ & $111.9 \mathrm{a}$ & 4194 a \\
\hline 10 & $58.3 \mathrm{c}$ & $96.2 \mathrm{a}$ & $37.8 \mathrm{ab}$ & $63.4 \mathrm{abc}$ & $38.4 \mathrm{abc}$ & $97.8 \mathrm{ab}$ & $3700 a b$ \\
\hline Mean & 59.1 & 96.4 & 37.3 & 55.9 & 34.2 & 88.5 & 3291 \\
\hline
\end{tabular}

${ }^{1}$ Data are averages for all three crosses made with each male parental line (male $x$ female lines A through C).

${ }^{2} \mathrm{MB}=$ midbloom, BL formation of black layer.

${ }^{3}$ Yield/day averaged over hybrids and replications.

${ }^{4}$ Means followed by the same letter are not significantly different.

lines in GY. Line 9 hybrids were the highest in all yield measurements, but they were intermediate for maturation time. Variation among the hybrids according to male-parental line was greater for GY than for maturation times. Therefore, the calculated daily yields were influenced more by the total yield of grain (GY) than by the duration of the growth periods. For the hybrids studied, then, the performance of the individual male line in hybrid combination (its combining ability) was important in determination of yields.

\section{INDIVIDUAL HYBRIDS}

The maturation time and grain yield for the individual hybrids are shown in table 4. To reach MB, hybrid A4 was slower than B4, which, in 
TABLE 4.-Maturation time and grain yield of hybrids of three female and seven male-parental sorghum lines (Puerto Rico, 1976)

\begin{tabular}{|c|c|c|c|c|c|c|c|}
\hline \multirow{3}{*}{ Hybrid' } & \multicolumn{3}{|c|}{ Maturation time (days) } & \multicolumn{3}{|c|}{ Grain yield/day $(\mathrm{kg} / \mathrm{ha})^{3}$} & \multirow{3}{*}{$\begin{array}{l}\text { Total } \\
\text { grain } \\
\text { yield }\end{array}$} \\
\hline & \multicolumn{2}{|c|}{ from planting to } & \multirow{2}{*}{$-\frac{\text { from }}{\mathrm{MB} \text { to } \mathrm{BL}}$} & \multicolumn{2}{|c|}{ from planting to } & \multirow{2}{*}{$\begin{array}{c}\text { from } \\
\text { MB to BL }\end{array}$} & \\
\hline & $\mathrm{MB}^{2}$ & $\mathrm{BL}^{2}$ & & MB & BL & & \\
\hline & & & & & & & $\mathrm{Kg} / \mathrm{ha}$ \\
\hline A4 & $62.2 \mathrm{a}^{4}$ & $98.8 \mathrm{abc}$ & 36.7 abcdef & 39.2 ef & $24.6 \mathrm{ef}$ & 66.5 ef & $2431 \mathrm{~g}$ \\
\hline B4 & 59.3 defg & 96.3 defg & 37.0 abcdef & $42.0 \mathrm{ef}$ & 25.9 ef & $67.3 \mathrm{ef}$ & $2491 \mathrm{~g}$ \\
\hline $\mathrm{C} 4$ & 58.7 fghi & 96.7 cdef & 38.0 abcd & 40.3 ef & $24.3 \mathrm{f}$ & $61.0 \mathrm{f}$ & $2350 \mathrm{~g}$ \\
\hline A5 & $61.8 \mathrm{ab}$ & $99.2 \mathrm{ab}$ & 37.3 abcde & $50.5 \mathrm{de}$ & 31.3 de & 82.8 de & $3100 \mathrm{f}$ \\
\hline B5 & 60.7 abcde & $95.8 \mathrm{efg}$ & 35.2 ef & $58.0 \mathrm{bcd}$ & $36.8 \mathrm{bcd}$ & 100.8 abcd & 3514 bcdef \\
\hline C5 & 58.3 fghij & $94.3 \mathrm{fgh}$ & 36.0 cdef & $55.6 \mathrm{~cd}$ & $34.3 \mathrm{~cd}$ & $89.7 \mathrm{~cd}$ & 3229 ef \\
\hline $\mathrm{A} 6$ & 60.2 bcdef & 97.0 bcde & 36.8 abcdef & $60.1 \mathrm{bcd}$ & 37.2 abcd & 97.9 abcd & 3607 abcdef \\
\hline B6 & 58.3 fghij & $93.2 \mathrm{~h}$ & $34.8 \mathrm{f}$ & $67.2 \mathrm{abc}$ & $42.0 \mathrm{ab}$ & $112.3 \mathrm{a}$ & 3906 abcde \\
\hline C6 & $56.3 \mathrm{k}$ & $93.0 \mathrm{~h}$ & 36.7 abcdef & $70.7 \mathrm{ab}$ & $42.6 \mathrm{ab}$ & $107.5 \mathrm{abc}$ & 3958 abcd \\
\hline A 7 & $61.3 \mathrm{abc}$ & $99.7 \mathrm{a}$ & $38.3 \mathrm{abc}$ & $37.3 \mathrm{f}$ & $23.0 \mathrm{f}$ & $59.9 \mathrm{f}$ & $2290 \mathrm{~g}$ \\
\hline B7 & $59.3 \mathrm{defg}$ & $95.8 \mathrm{efg}$ & 36.5 bcdef & $31.4 \mathrm{f}$ & $19.5 \mathrm{f}$ & $51.2 \mathrm{f}$ & $1866 \mathrm{~g}$ \\
\hline $\mathrm{C} 7$ & 57.0 hijk & 95.7 efg & $38.7 \mathrm{ab}$ & $37.3 \mathrm{f}$ & $22.1 \mathrm{f}$ & $54.9 \mathrm{f}$ & $2119 \mathrm{~g}$ \\
\hline $\mathrm{A} 8$ & 60.8 abcd & $99.7 \mathrm{a}$ & $38.8 \mathrm{ab}$ & $55.2 \mathrm{~cd}$ & $33.6 \mathrm{~cd}$ & $86.4 \mathrm{~d}$ & 3355 def \\
\hline B8 & 58.2 ghijk & 95.8 efg & 37.7 abcd & $59.0 \mathrm{bcd}$ & $35.8 \mathrm{bcd}$ & $91.1 \mathrm{bcd}$ & 3432 cdef \\
\hline $\mathrm{C} 8$ & $56.8 \mathrm{ijk}$ & 94.8 efgh & $38.0 \mathrm{abcd}$ & $66.5 \mathrm{abc}$ & 39.9 abc & 99.7 abcd & 3780 abcdef \\
\hline A9 & $61.0 \mathrm{abcd}$ & $98.7 \mathrm{abc}$ & $37.7 \mathrm{abcd}$ & $69.2 \mathrm{ab}$ & $42.7 \mathrm{ab}$ & $111.9 \mathrm{a}$ & $4217 \mathrm{ab}$ \\
\hline B9 & 59.8 cdefg & $95.7 \mathrm{efg}$ & 35.8 def & $68.7 \mathrm{ab}$ & $43.0 \mathrm{ab}$ & $114.7 \mathrm{a}$ & $4104 \mathrm{abc}$ \\
\hline C9 & $56.8 \mathrm{ijk}$ & $95.8 \mathrm{efg}$ & $39.0 \mathrm{a}$ & $75.0 \mathrm{a}$ & $44.5 \mathrm{a}$ & $109.2 \mathrm{ab}$ & 4261 a \\
\hline $\mathrm{A} 10$ & 59.7 cdefg & $98.2 \mathrm{abcd}$ & $38.5 \mathrm{ab}$ & $64.5 \mathrm{abc}$ & $39.3 \mathrm{abc}$ & $100.3 \mathrm{abcd}$ & 3851 abcde \\
\hline $\mathrm{B} 10$ & $58.8 \mathrm{efgh}$ & 96.2 defg & 37.3 abcde & $58.6 \mathrm{bcd}$ & $35.8 \mathrm{bcd}$ & 92.5 bcd & 3452 cdef \\
\hline $\mathrm{C} 10$ & $56.5 \mathrm{jk}$ & $94.2 \mathrm{gh}$ & $37.7 \mathrm{abcd}$ & $67.2 \mathrm{abc}$ & $40.3 \mathrm{abc}$ & $100.5 \mathrm{abcd}$ & 3795 abcdef \\
\hline Mean & 59.1 & 96.4 & 37.3 & 55.9 & 34.2 & 88.5 & 3291 \\
\hline
\end{tabular}

' Key: $\mathrm{A} 4$ = the hybrid made by crossing female $\mathrm{A} \times$ male $4, \mathrm{~B} 4=$ female $\mathrm{B} \times$ male 4 , etc.

${ }^{2} \mathrm{MB}=$ midbloom, $\mathrm{BL}=$ formation of black layer.

${ }^{3}$ Yield/day averaged over replications.

${ }^{4}$ Means followed by one or more letters in common do not differ significantly. 
turn, was slower than C4. This same pattern held in the sets of hybrids made with male-parental lines 5 through 10. Many differences in time to $\mathrm{MB}$ among hybrids within sets were statistically significant. Time to $\mathrm{MB}$ ranged from 56.3 to 62.2 days. For sets of hybrids with the same male parent, time to BL formation followed the same general pattern as time to $\mathrm{MB}$, except that female-line $\mathrm{B}$ hybrids were not always later than female-line $\mathrm{C}$ hybrids. The range in time to $\mathrm{BL}$ formation was 93.0 to 99.7 days. Generally, time to progress from $\mathrm{MB}$ to $\mathrm{BL}$ formation was more for both female-line A hybrids and female-line C hybrids than for B hybrids, but the differences were small.

The GYMB's were most often highest for the female-line C hybrids. The differences in GYMB among hybrids within sets having a given male parent were smaller than the differences among such sets. The range in GYMB was 31.4 to $75.0 \mathrm{~kg} / \mathrm{ha}$. The GYBL's were most often highest for female-line $\mathrm{C}$ hybrids and lowest for the female-line $\mathrm{A}$ hybrids, and like GYMB, GYBL differed more among sets than within those having a given male parent. The range in GYBL was 19.5 to $44.5 \mathrm{~kg} / \mathrm{ha}$. The GYMB-BL ranged from 51.2 to $114.7 \mathrm{~kg} / \mathrm{ha}$. Inasmuch as the period from $\mathrm{MB}$ to $\mathrm{BL}$ formation was much shorter than the other maturation periods considered, and the maturation periods entered into calculation of the daily yields, the differences in GYMB-BL among individual hybrids and among sets of hybrids were larger than the differences in GYMB and GYBL. Hybrids of lines 6, 9, and 10 had highest GYMB-BL's; and hybrids of lines 4 and 7, the lowest.

The GY ranged from 1866 to $4261 \mathrm{~kg} / \mathrm{ha}$. Hybrids of lines 6, 9, and 10 produced the most grain whereas hybrids of lines 4 and 7 produced the least. Although differences in both maturation times and GY affected the calculated daily yields, differences in GY had the greatest effect on the daily increments. Nonetheless, in five of the seven sets of hybrids, the hybrid (a $\mathrm{C}$ hybrid in each case) with the shortest time to $\mathrm{MB}$ had a GYMB equal to or greater than those of the hybrids with longer times to $\mathrm{MB}$. Also, in four sets of hybrids, the hybrid (a C hybrid in three cases) with the shortest time to BL formation had a GYBL higher than those of the later maturing hybrids within the same set.

\section{MALE PARENTAL LINES SELFED}

The maturation times and grain yields for the seven male-parental lines selfed are shown in table 5. Time to $\mathrm{MB}$ and to $\mathrm{BL}$ formation was longer for the male-parental lines than for any of their hybrids. Lines 4 , 7 , and 8 were the earliest to reach MB in 64 to 65 days; lines 5 and 9 were the latest to reach $\mathrm{MB}$ in 66 to 68 days. Lines 4 and 6 were the fastest to form BL (99 days), while lines 5 and 6 were fastest to progress from MB to BL formation (33 days); line 6's hybrids were among the fastest. Lines 
7 and 8 were the slowest to form BL (105 days) and to progress from MB to $\mathrm{BL}$ formation (40 days).

The GY ranged from 1951 to $3609 \mathrm{~kg} / \mathrm{ha}$. The GY, GYMB, GYBL, and GYMB-BL were highest for lines 6, 9, and 10. Also these lines produced high-yielding hybrids. Low GY contributed to the low GYMB, GYBL, and GYMB-BL for lines 4, 5, 7, and 8. Three of the five earliest lines had the highest GYMB's and the highest GYBL's.

TABLE 5.-Performance, when selfed, of seven sorghum lines that were used as male parents (Puerto Rico, 1976)

\begin{tabular}{|c|c|c|c|c|c|c|c|}
\hline \multirow{3}{*}{ Male } & \multicolumn{3}{|c|}{ Maturation time (days) } & \multicolumn{3}{|c|}{ Grain yield/day $(\mathrm{kg} / \mathrm{ha})^{2}$} & \multirow{3}{*}{$\begin{array}{l}\text { Total } \\
\text { grain } \\
\text { yield }\end{array}$} \\
\hline & \multicolumn{2}{|c|}{ from planting to } & \multirow{2}{*}{$\frac{\text { from }}{\mathrm{MB} \text { to } \mathrm{BL}}$} & \multicolumn{2}{|c|}{ from planting to } & \multirow{2}{*}{$\frac{\text { from }}{\text { MB to } B L}$} & \\
\hline & $\mathrm{MB}^{1}$ & $\mathrm{BL}^{\prime}$ & & $\mathrm{MB}$ & $\mathrm{BL}$ & & \\
\hline & & & & & & & $K g / h \alpha$ \\
\hline 4 & $64.0 \mathrm{c}^{3}$ & $99.3 \mathrm{~cd}$ & $35.3 \mathrm{~b}$ & $30.5 \mathrm{c}$ & $19.7 \mathrm{c}$ & $55.5 \mathrm{~b}$ & $1951 \mathrm{c}$ \\
\hline 5 & $67.8 \mathrm{a}$ & $100.7 \mathrm{bc}$ & $32.8 \mathrm{c}$ & $31.1 \mathrm{c}$ & $20.9 \mathrm{c}$ & $63.9 \mathrm{~b}$ & $2100 \mathrm{c}$ \\
\hline 6 & $66.0 \mathrm{~b}$ & $98.7 \mathrm{~d}$ & $32.7 \mathrm{c}$ & $45.7 \mathrm{~b}$ & $30.5 \mathrm{~b}$ & $92.0 \mathrm{a}$ & $3006 \mathrm{~b}$ \\
\hline 7 & $64.7 \mathrm{bc}$ & $104.5 \mathrm{a}$ & $39.8 \mathrm{a}$ & $31.6 \mathrm{c}$ & $19.5 \mathrm{c}$ & $51.3 \mathrm{~b}$ & $2041 \mathrm{c}$ \\
\hline 8 & $65.2 \mathrm{bc}$ & $105.2 \mathrm{a}$ & $40.0 \mathrm{a}$ & $34.7 \mathrm{c}$ & $21.5 \mathrm{c}$ & $56.6 \mathrm{~b}$ & $2254 \mathrm{c}$ \\
\hline 9 & $66.3 \mathrm{ab}$ & $101.5 \mathrm{~b}$ & $35.2 \mathrm{~b}$ & $54.4 \mathrm{a}$ & $35.6 \mathrm{a}$ & $102.8 \mathrm{a}$ & 3609 a \\
\hline 10 & $66.0 \mathrm{~b}$ & $101.5 \mathrm{~b}$ & $35.5 \mathrm{~b}$ & $49.8 \mathrm{ab}$ & $32.4 \mathrm{ab}$ & $93.1 \mathrm{a}$ & $3286 \mathrm{ab}$ \\
\hline Mean & 65.7 & 101.6 & 35.9 & 39.7 & 25.7 & 73.6 & 2607 \\
\hline
\end{tabular}

${ }^{1} \mathrm{MB}=$ midbloom, $\mathrm{BL}=$ formation of black layer.

${ }^{2}$ Yield/day averaged over replications.

${ }^{3}$ Means followed by one or more letters in common do not differ significantly.

\section{Conclusions}

There were significant differences in days to $\mathrm{MB}$, days to $\mathrm{BL}$ formation, and days from $\mathrm{MB}$ to $\mathrm{BL}$ formation among the means of the hybrids for the female-parental lines. Female-parental line C (Redlan) was earlier to reach $\mathrm{MB}$ and $\mathrm{BL}$ formation.

There were significant differences in GYMB and GYBL among the means of the hybrids for the female-parental lines, and female-parental line C (Redlan) had the highest yields.

For the means of the hybrids for the male-parental lines, there were significant differences in days to $\mathrm{MB}$, days to $\mathrm{BL}$ formation, days from MB to BL, GYMB, GYBL, GYMB-BL, and for GY.

Line 6 hybrids required the fewest days to $\mathrm{MB}$, to $\mathrm{BL}$, and from $\mathrm{MB}$ to $\mathrm{BL}$ formation, yet they had the next-to-highest GYMB, GYBL, and GYMB-BL.

For the means of the individual hybrids, there were significant differences for days to MB, BL, MB-BL, GYMB, GYBL, GYMB-BL, and GY.

Individual hybrids made on female-parental line $\mathrm{C}$ usually required the fewer days to $\mathrm{MB}$, and to $\mathrm{BL}$ formation than hybrids made on female- 
parental lines A and B of the same sets, while female-parental line B hybrids usually had fewer days from $\mathrm{MB}$ to $\mathrm{BL}$.

Individual hybrids made on female-parental line $\mathrm{C}$ were most often highest for GYMB, and GYBL. Hybrids of lines 6, 9, and 10 had the highest GYMB, GYBL, and GYMB-BL.

For the male-parental lines selfed, there were significant differences for $\mathrm{MB}, \mathrm{BL}, \mathrm{MB}$ to BL, GYMB, GYBL, GYMB-BL, and GY.

The GY, GYMB, GYBL, and GYMB-BL were highest for lines 6, 9, and 10. Three of the five earliest male lines had the highest GYMB's and the highest GYBL's.

In this experiment Redlan appeared to produce more hybrids with early maturation time and high GY/day. Among the male-parental lines 6,9 , and 10 generally produced hybrids with high GY/day. However, all three male-sets of hybrids were too tall for machine harvest, and in addition they produced high tannin grain.

Hybrids of male-parental line 8 produced GY's not significantly different from lines 6 and 10, and in addition they were short enough for machine harvest and they produced low tannin grain. C (Redlan) $\times 8$ appeared most promising for rapid maturation and high GYMB, GYBL, GYMB-BL, and total GY.

In the tropics, where several crops may be harvested annually, sorghum hybrids and cultivars with the highest yield for each day they occupy space in the field would be most desirable. The data presented here indicated that some hybrids produced more grain/day as they matured faster than other hybrids. The use of these more rapidly productive hybrids should increase annual grain yield under tropical conditions.

Maximum production/day is probably less important in temperate climates, where the length of the growing season permits only one crop/ year, and where that season is long enough for maturation of cultivated sorghums. High production/day may be more important in areas of the temperate zone where double cropping is possible, or where the growing season is short.

\section{RESUMEN}

Siete líneas de sorgo de grano y sus híbridos $\left(F_{1}\right)$ fueron evaluados en la finca experimental del Instituto Mayaguiezano de Agricultura Tropical. Tres líneas androestériles, CK-60, Martin y Redlan, se utilizaron como progenitores femeninos.

La formación de "black layer" (BL) (tejido oscuro que se forma en la base de la semilla), se utilizó como índice de madurez físiológica. La BL sirvió de ayuda en la búsqueda de diferencias en la producción de grano por día entre los siete padres e híbridos estudiados.

Los progenitores masculinos y sus híbridos fueron evaluados en término de producción de grano por día desde la siembra hasta la mitad de la floración (GYMB), desde la siembra hasta la formación de BL (GYBL), desde la mitad de la floración (MB) hasta la formación de BL (GYMB-BL) y para la producción de grano a la formación de BL (GYBL).

Los híbridos con el progenitor femenino androestéril Redlan, fueron los primeros en alcanzar la MB y la formación de la BL, y arrojaron los valores más elevados de GYMB y GYBL. Por otro lado, los híbridos con los progenitores masculinos 6,9 y 10 fueron los 
primeros en alcanzar la MB y Ia formación de la BL. Además, éstos arrojaron los valores más elevados en término de GYMB, GYBL, GYMB-BL y GY. Para los híbridos individuales, diferencias tanto en tiempo de madurez y GY contribuyeron a diferencias en producción de grano por día, pero la influencia mayor fue la de GY. Sin embargo, en cinco de los siete grupos de híbridos con un progenitor masculino dado (A4, B4, C4), el híbrido (con el progenitor femenino Redlan en cada caso), que fue el primero en alcanzar la MB produjo un GYMB igual o mayor que aquéllos híbridos que fueron menos lentos en alcanzar la MB. En término de los progenitores masculinos, las líneas 6, 9 y 10 arrojaron los valores más elevados de GY, GYMB, GYBL y GYMB-BL. Esas líneas estaban entre las cinco más precoces.

En los trópicos, en donde se pueden lograr varias cosechas de una misma siembra, híbridos de sorgo o cultivares con un alto rendimiento por día deben ser los más deseables. Este estudio identifica híbridos con esas características.

\section{LITERATURE CITED}

1. Daynard, T. B. and Duncan, W. G., 1969. The black layer and grain maturity in corn, Crop Sci. 9: 473-476.

2. Daynard, T. B., Tanner, J. W., and Duncan, W. G., 1971. Duration of the grain filling period and its relationship to grain yield in corn, Zea mays L., Crop Sci. 11: 45-48.

3. Eastin, J. D., Hultquist, J. H., and Sullivan, C. Y., 1973. Physiologic maturity in grain sorghum, Crop Sci. 13: 175-178.

4. Kumar, M., 1975. Use of black layer to study dry matter accumulation in grain sorghum, M.S. Thesis, Oklahoma State Univ.

5. Lopez, E., 1973. Seed maturation in corn, M.S. Thesis, Mississippi State Univ.

6. Quinby, J. R., 1972. Grain filling period of sorghum parents and hybrids, Crop Sci. 12: 690-691.

7. Sotomayor-Ríos, A. and Miller, F. R., 1977. Performance of ten grain sorghum lines from the conversion program. J. Agri. Univ., P. R. 61(4): 443-449.

8. Steel, R. G. D. and Torrie, J. H., 1960. Principles and procedures of statistics, McGrawHill Book Co., Inc., New York.

9. Stephens, J. C., Miller, F. R., and Rosenow, D. T., 1967. Conversion of alien sorghums to early combine genotypes, Crop Sci. 7: 396. 